\title{
The Challenges of Learning English Skills and the Integration of Social Media and Video Conferencing Tools to Help ESL Learners Coping with the Challenges during COVID-19 Pandemic: A Literature Review
}

\author{
Yong Hua Ying ${ }^{1,2}$, Winson Eng Wei Siang2,3, Maslawati Mohamad² \\ ${ }^{1}$ Department of General Studies, Politeknik Mukah, Sarawak, Malaysia \\ ${ }^{2}$ Faculty of Education, Universiti Kebangsaaan Malaysia, Bangi, Malaysia \\ ${ }^{3}$ Sekolah Jenis Kebangsaan Cina Ladang Grisek, Johor, Malaysia \\ Email: ^yonghuaying8071@gmail.com,winsonews@gmail.com, maslawati@ukm.edu.my
}

How to cite this paper: Ying, Y. H., Siang, W. E. W., \& Mohamad, M. (2021). The Challenges of Learning English Skills and the Integration of Social Media and Video Conferencing Tools to Help ESL Learners Coping with the Challenges during COVID-19 Pandemic: A Literature Review. Creative Education, 12, 1503-1516. https://doi.org/10.4236/ce.2021.127115

Received: June 6, 2021

Accepted: July 6, 2021

Published: July 9, 2021

Copyright $\odot 2021$ by author(s) and Scientific Research Publishing Inc. This work is licensed under the Creative Commons Attribution International License (CC BY 4.0).

http://creativecommons.org/licenses/by/4.0/ (c) (i) Open Access

\begin{abstract}
During the COVID-19 pandemic, the abrupt closures of all learning institutions have caused English as second language (ESL) learners to have significant difficulties learning the English language especially for speaking skills. Speaking is one of the most important skills to learn because it is the primary mode of communication around the world. However, the majority of ESL learners are still trying to improve their English speaking abilities. Since the implementation of the COVID-19 lockdowns, e-learning has been a well-known solution all over the world. Learners and educators need more time to adjust to online teaching and learning because most of them are exploring new technical innovations and strategies to be used in the classroom. As a result, this study includes a literature review on the challenges ESL learners encounter in learning speaking skills, as well as the use of social media and video conferencing tools to teach speaking skills. Lack of motivation and self-confidence, fear, hesitation, and limited vocabulary are some of the challenges faced by ESL learners. Hence, it is vital to determine the technology intervention used in teaching and developing speaking skills among these learners based on previous study. During the COVID-19 pandemic, some of the interventions in teaching speaking skills included utilizing social media and video conferencing applications like Facebook, WhatsApp, and others for online teaching and learning. Educators of English as a Second Language (ESL) might then pick the ones that would work best in their particular classroom.
\end{abstract}




\section{Keywords}

E-Learning, Learning of Language Skills, Social Media, Video Conferencing Tools, COVID-19 Pandemic

\section{Introduction}

In the globalized twenty-first century era, language proficiency promotes cooperation and communication among people from diverse cultural backgrounds in all facets of life, education and work. Language learning must therefore be a lifelong commitment, carried out in a number of ways to meet social, occupational and educational needs, as well as personal needs and desires (Kukulska-Hulme, Lee, \& Norris, 2017). The English language is widely regarded as the lingua franca and the most widely spoken language in the world (Yen \& Mohamad, 2020). Due to the needs and value of the English language in current global period, English as a second language (ESL) learners travel across the world to learn the language. As a result, much work has been put into finding suitable approaches for learning English. Learning English as a second language is a challenging task. It will take a collaborative, massive and extraordinary effort from both learners and educators (Khasbani, 2018). As a result of societal globalization, the teaching of English in Malaysian Higher Education has increasingly shifted from grammar translation to communicative approach (Zakaria \& Shah, 2019). This approach allows learners to actively engage in class and helps them improve their English especially in speaking and listening skills. Speaking is one of the most important skills to learn because it is used as a form of communication all over the world. Though listening, speaking, reading, and writing abilities are all important, speaking competence generally takes precedence over the others since speaking or, in other words, communication occurs frequently in one's everyday life, both in formal and informal settings. Furthermore, communication is one of the components in the $4 \mathrm{Cs}$ of the $21^{\text {st }}$ century skills, emphasizing the relevance of the talent. As a result, the ultimate objective for many nations' governments to assure the empowerment of speaking skills among students is expressed in the education policy in order to generate competent English language speakers.

The unexpected outbreak of the deadly disease COVID-19 has caused worldwide trauma. COVID-19 pandemic, which began in March 2020, has had both direct and indirect impacts on human lives around the world (Shahzad, Hussain, Sadaf, Sarwat, Ghani, \& Saleem, 2020). Some daily activities, such as travelling and going outdoors, have been temporarily prohibited to reduce the transmission of the virus. The repercussions of COVID-19 have led almost every region and educational institutions to be operating with the new normal. Many countries have imposed lockdowns that include the permanent closing of all educational institutions. In order to avoid COVID-19 from spreading and transmit- 
ting, all face-to-face learning practices in the classroom have been suspended (Othman, Kadar, Umar, \& Ahmad, 2020). This situation puts the global education system under strain, pushing educators to switch to online teaching and learning instantaneously. Both educators and learners are turning to e-learning models because of COVID-19. Each academic institution has shed some light on the current pandemic problems in order to determine the best course of action to deal with the current challenges associated with e-learning. Many educators and lecturers, especially in different regions, are not yet proficient in using e-learning applications for teaching and learning process. According to studies by (Rohman, Marji, Sudjimat, Sugandi, \& Nurhadi, 2020; Wargadinata, Maimunah, Dewi, \& Rofiq, 2020), most learners have negative attitudes toward e-learning, though, they do agree, that e-learning is the best option during the pandemic. In this circumstance, video conferencing platforms such as Zoom, Microsoft Teams, Skype and WebEx, as well as Learning Management Systems (LMS) such as Schoology, Canvas, Google Classroom, CIDOS, Moodle and social media (Facebook, WhatsApp, Instagram, YouTube) are heavily used as e-learning applications. With the emergence of e-learning environments, the learning process will not be interrupted due to the closing of the academic institution during COVID-19 pandemic. Despite this, some institutions have improved their abilities to offer course material online, engage learners in learning and conduct assessments.

Due to the sudden closure of schools and institutions, ESL learners have begun to face significant obstacles in learning and improvising the English language with regard to the COVID-19 pandemic (Verawardina, Asnur, Lubis, Hendriyani, Ramadhani, Dewi, \& Darni, 2020). It has made a significant difference in terms of language learning especially speaking skills. According to Yen and Mohamad (2020), the decision to close all schools and eliminate face-to-face classrooms has resulted in a survival situation and adaptation to the "new normal." The majority of English learners, particularly English as Second Language (ESL) students, are trying to improve their speaking abilities. It becomes an additional problem during online learning. According to studies conducted by Savasci (2013) and Idrus and Salleh (2007), high levels of anxiety generated by the fear of being evaluated, the educator's teaching technique, and the learners' culture are all factors that contribute to ESL students' reluctance to use the target language. Previous studies also state the key problems that hinder ESL learners' speaking capabilities include a lack of desire and self-confidence, nervousness, inhibition, and a lack of vocabulary knowledge (Yen \& Mohamad, 2020). As a result, it is critical to find potential solutions for overcoming ESL learners' challenges and improving their speaking abilities. There are several ways that have been demonstrated to be beneficial in overcoming the problems faced by ESL students and improving their speaking abilities. Within and beyond the classroom, the ideas and tactics include utilizing social media such as Facebook, WhatsApp, YouTube, and so on. This paper is a literature review about the con- 
cept of e-learning during COVID-19 pandemic, challenges faced by ESL learners in the learning of speaking skills and the intervention of social media and video conferencing tools to help ESL Learners coping with the challenges during COVID-19 pandemic.

\section{Literature Review}

\subsection{The Concept of E-Learning during COVID-19 Pandemic}

The term "e-learning" refers to the use of new technology and the Internet to improve learning quality by making materials and remote interfaces more accessible. The terms " $21^{\text {st }}$ century education" and " $21^{\text {st }}$ century skills" are commonly used nowadays. The definition of $21^{\text {st }}$ century education means that educators develop their teaching to ensure that their learners possess the skills they need to succeed in the current world. Mohamad, Arif and Noor (2020) state that Information and communication technology (ICT) is used to improve Generation $\mathrm{Z}$ learners' understanding in order to promote the essence of $21^{\text {st }}$-century learning. This move aligns with the seventh shift in the Malaysian Education Blueprint (MEB) 2013-2025 which is to uplift ICT to leverage successful learning across the country. In addition, e-learning refers to the usage of the Internet to distribute, monitor and execute courses. It is the use of advanced technology to guide, plan and distribute learning materials, along with encouraging two-way interaction between learners and educators. Chat rooms, polls, quizzes, discussion boards and presentations may all be used to facilitate constructive and easy ways to achieve learning goals. As for the learning management systems, most institutions opt for Microsoft Teams, Google Meet, Zoom, Skype, WebEx and Adobe Link, as well as video conferencing softwares. It is inevitable for educators and learners to utilize technology for educational purposes during the pandemic (Mailizar, Almanthari, Maulina, \& Bruce, 2020; Kerres, 2020; Wang, Ng, \& Brook, 2020). On another note, e-learning, an integrating medium for teaching and learning that uses a centralised framework to manage interaction during instructional activities is one of the technologies used during the COVID-19 pandemic lockdown (Sukendro, Habibi, Khaeruddin, Indrayana, Syahruddin, Makadada, \& Hakim, 2020). The aim of online-learning integration in language classrooms before COVID-19 is to make conventional learning more effective and successful. Apparently, the integration of e-learning can help curb the transmission of COVID-19 virus. In addition, the move is to ensure the continuity of education during the outbreak (Rasmitadila, Aliyyah, Rachmadtullah, Samsudin, Syaodih, Nurtanto, \& Tambunan, 2020). Kisanjara (2020) also mentions e-learning is when educators and learners use technologies and the Internet to conduct teaching and learning sessions. In other words, e-learning also entails web design and optimization of ICT integration. Similarly, the transfer and provision of all teaching materials to learners via Internet can be maximised. 


\subsection{Challenges Faced by ESL Learners in the Learning of Speaking Skills during COVID-19 Pandemic}

Learners' lack of confidence and communication through virtual lessons has made it much more difficult for them to speak or utter the words appropriately (Sayuti, Teh, Saimi, Bakar, Dawawi, \& Mohamad, 2020). Learners have difficulty expressing themselves because they are tentative, hesitant and fearful of making mistakes. They often lack adequate vocabulary and practice, making it difficult for them to converse fluently in English (Syafiq, Rahmawati, Anwari, \& Oktaviana, 2021). Deprivation of language content causes the learners to be anxious as they are unable to speak. Even if they have anything to say, they are unable to do so because they are afraid of making grammatical mistakes and being laughed at by their peers (Meinawati, Harmoko, Rahmah, \& Dewi, 2020). Unlike traditional classrooms, e-learning limits peer interaction. Hernandez \& Flórez (2020) mention that peer interaction in speaking lessons is insufficient for learners to practise their skills. Even though teachers capture the attention of ESL learners by engaging them in interesting and enjoyable activities that encourage them to speak in class, it is hard during online mode because not all learners get used to E-learning and it is even tougher for teachers to get feedback from passive learners (Kaur \& Aziz, 2020). Adedoyin and Soykan (2020) emphasise in their study, learners are often placed in circumstances where they have to learn languages on their own during the COVID-19 pandemic, leading them to struggle to understand and overcome the challenge.

In English Language Learning, learners' engagement is affected by psychological factors (Sison \& Bautista, 2021). A significant problem associated with e-learning is the lack of effective contact with educators (Lestiyanawati \& Widyantoro, 2020; Ariyanti, 2020). Learners need two-way communication which can be difficult to achieve. Learners feel demotivated to learn in such circumstances because they are constantly confronted with a computer (Toquero, 2020). They seldom have time to do e-learning because it needs too much time for them to explore their interpretation of the subject. Despite the fact that e-learning is a daunting task, it necessitates efforts such as recording, reading, memorizing and consuming online-based learning media (Simamora, 2020) especially for English Oral Presentation or speaking assessment. This is a situation in which learners must adapt rapidly; more specifically in an emergency learning situation (Pace, Pettit, \& Baker, 2020). For those who cannot adapt themselves because of poor interpretation towards subjects learned, especially English language, unable to submit assignment on time due to poor Internet coverage and are unable to finish it as well as the fear of losing marks increases the level of stress among the learners (Aboagye, Yawson, \& Appiah, 2020). Furthermore, without assistance and support from friends, families, schools, government and policymakers in the midst of COVID-19 pandemic, learners find e-learning to be tedious (Allam, Hassan, Mohideen, Ramlan, \& Kamal, 2020). Hence, they lose their interests and motivation to learn. Some learners admit that they do not 
have a comfortable learning atmosphere at home and the fact that they are forced to engage in household chores during the lockdown, bring about negative impacts on their studies and leaving them depressed and despondent (Mishra, Gupta, \& Shree, 2020).

Besides, physical issues, such as eye pressure, are common challenges among learners and can make them feel uneasy throughout the learning process (Octaberlina \& Muslimin, 2020). Learner engagement and satisfaction are critical aspects to the E-learning process to ensure their academic development especially in second language learning (Chung, Subramaniam, \& Dass, 2020; Pazilah, Hashim, \& Yunus, 2019). Learners are more motivated to participate in online teaching and learning when instructors provide prompt reaction and interact with them. These are the steps that will lead to the anticipated teaching and learning outcomes.

\subsection{Intervention of Social Media and Video Conferencing Tools to help ESL Learners Coping with the Challenges during COVID-19 Pandemic}

Independent study is one of the most common and important ways to learn a language, particularly during the COVID-19 outbreak. The learners' intention to learn language skills especially speaking skill is a hallmark of the $21^{\text {st }}$ century learning for academic and employability purposes. One of the aspects is the ability to apply the knowledge of ICT in language learning particularly the technical skill (Kho, Chai, \& Lim, 2016). Educators ought to improve their capability to be more innovative in their use of technology to cater to their learners' needs across several disciplines. The teaching and learning should not be limited to the classroom; technology should be utilized by both educators and learners to make language learning materials available. Creating and sustaining supportive learning surroundings, developing learning communities, providing consistent input on time and using the best technologies to produce the right content are all examples of how e-learning can provide interesting learning opportunities for learners via online. Mustafa (2015) emphasises that learners would not be bored when engaging in e-learning activities. Higher education institutions are increasingly using e-learning platforms to replace traditional teaching approaches especially during COVID-19 pandemic.

In the past study by Cakrawati (2017), learners have stated that e-learning platforms assist them in practising language skills and learning new English vocabularies while they are learning English. Learners choose to learn languages using online resources as the number of portable, digital, Android, smart and intelligent devices keeps growing. Many learners nowadays have offline or online dictionaries installed on their devices that can assist them in deciphering the meanings of new terms. Aside from that, ESL educators find certain applications to be extremely helpful when creating specific assignments for their learners. According to Mohamad, Rashid and Wan Mohamad (2017), an electronic dictionary is convenient and time-saving for learners to look for the definitions of 
new terms. Some previous studies have proved that learners' confidence is enhanced as a result of this advanced applications, which enables them to become more independent learners and take responsibility for their learning because they are in control of their own learning pace (Rashid, Yunus, \& Mohamad, 2015; Mohamad et al., 2017; Naz, Rasheed, \& Rasheed, 2019; Oksana \& Olena, 2021).

Similarly, learners are thrilled to learn English in social media platforms such as Facebook, WhatsApp, Instagram and YouTube (Ghounane, 2020). Learners from all over the world can interact and discuss a range of topics on these social networking sites (Musa, Mohamed, Mufti, Latiff, \& Amin, 2015). The use of mobile-mediated communication allows learners to study not only the standard form of the language, but also its varieties. A study from Al-Jumaili, Al-Rekabi, Alsawad, Allela, Ryan Carnahan, Saaed et al. (2017) indicates that learners prefer to use Facebook for academic purposes because the chat functions and other communicating features are considered to be user-friendly. Faryadi (2017) revealed that, in addition to acquiring new terms and terminology, Facebook helped students enhance their English speaking skills. His findings also show that Facebook creates an environment that encourages English language learning and improves Malaysian learners' attitudes, confidence, contentment, motivation, and perceptions about learning English speaking skills. According to Low and Warawudhi (2016), students' enthusiasm and attitudes toward learning English can be boosted through Facebook, as well as educator-learner interaction. In their study, out-of-class activities reportedly resulted in more engagement between students and Facebook can be a useful tool in teaching speaking skills to a big class with mixed-ability learners. Moreover, Dizon (2015) states in his study, Facebook has the potential to improve language instruction and extend communication beyond the classroom walls. Its ease of use allows students to communicate both synchronously and asynchronously, while also reducing the anxiety of students who are afraid to utilize the second language.

On the other hand, WhatsApp is also a popular social media platform in Malaysia. Malaysians are familiar with the use of WhatsApp, so there would be no need for participants to receive any instruction (Suhaimi, Mohamad, \& Yamat, 2019). In Malaysia, the studies indicate that the role of WhatsApp in the educational setting is providing educators and learners with input and allows them to interact more efficiently and effectively (Mistar \& Embi, 2016; Mbukusa, 2018; Suhaimi et al., 2019). During COVID-19 pandemic, this cost-effective and user-friendly application has become the online platform that educators use to monitor their learners' learning process. They use WhatsApp for one-on-one text exchanges with learners to discuss their specific needs especially in the teaching of English. Rahaded, Puspitasari \& Hidayati (2020) did research on undergraduate EFL students' learning processes. Despite the small number of participants, the results show that WhatsApp facilitates learning and fosters 
problem solving, as well as assisting students in collaborating and improving their communication skills as they prepare to study. In a university context, an Indonesian study by Manan (2017) demonstrated that using WhatsApp could fully support and increase learners' conversational abilities. Learners, according to Manan, utilize the software in a pleasant manner because there are no obstacles and communication problems are minimized. Manan also mentioned that learners could improve their vocabulary by using WhatsApp. Furthermore, WhatsApp has been widely used to exchange conversations, set lecture notifications, remind task due dates and alert submission deadlines (Asmara, 2020). Since WhatsApp is a widespread social networking application that enables users to deliver and receive texts, audios, images, videos, documents, places, voice calls and create groups, learners' speaking skills especially will be improved indirectly (Jasrial, 2018; Che Wil, Yunus, \& Suliman, 2019; Fauzi \& Angkasawati, 2019; Azam, Fadhil, \& Yunus, 2019). Learners may also interact with their lecturer through WhatsApp during office hours, regardless of time limitation or physical distance. As a result, the lecturer will provide immediate feedback to each learner. Effective communication is a critical component of e-learning (Suvarchala Rani, Rajini, \& Lal, 2020; Famularsih, 2020). Using WhatsApp to enhance the learning process and ease lecturers to communicate with learners at their leisure pace will improve the learning experience particularly for ESL teaching (Jasrial, 2018).

Previous findings also state that e-learning assists learners in developing their English listening and speaking skills since both skills are adapted when learners have doubt on the lectures (Layali \& Al-Shlowiy, 2020; Rajendran \& Yunus, 2021). Since the use of digital resources in lesson delivery is becoming the standard, there is no lack of tools available for educators who use e-learning in education, especially in the teaching and learning of speaking skills. In a study by Lim and Melor (2021), educators could use the interactive resources at their disposal to provide feedback to learners and engage them in a constructive engagement. According to Arkorful and Abaidoo (2015), e-learning is the best strategy for teaching and learning speaking skills because it is extremely versatile when time and location constraints are taken into account. It is also a very effective way of delivering lessons online because educators have easy access to a wealth of knowledge from a variety of online tools. e-learning is often seen as a fun way of teaching and learning speaking skills because it can boost learners' confidence and promote cooperation by engaging multimedia platforms and this is proved by several past studies (Ghavifekr, Kunjappan, Ramasamy, \& Anthony, 2016; Yilmaz, 2017; Rafiq, Hussain, \& Abbas, 2020). Furthermore, learners also love the independent learning, flexibility and immersive learning because they can access information outside the class according to their flexibility of time. Another study by Alhumaid, Ali, Waheed, Zahid and Habes (2020) also stresses that the use of online teaching and learning enhances learners' English language learning. 


\section{Conclusion}

This study presents a literature review of ESL learners' obstacles in learning speaking skills as well as the interventions use in teaching speaking skills during COVID-19 pandemic. This is mostly due to a problem that is circulating among ESL learners around the world, in which the majority of English learners, particularly ESL learners, are still failing to build their speaking skills. As a result, it is evident how crucial speaking skills are, especially in the twenty-first century. It's critical to recognize the obstacles that ESL students experience during the learning process, particularly when it comes to learning to communicate successfully during a pandemic. Motivation, self-confidence, anxiety, hesitation, and a limited vocabulary are some of the issues that ESL students confront. As a result, from previous studies, it is vital to determine the strategies used by English language educators in teaching and strengthening speaking abilities among ESL learners during the COVID-19 pandemic. English educators can choose from a list of interventions used by other educators to see which ones might work in their own classroom.

Apart from that, integrating social media and videoconferencing tools is critical in overcoming learners' hurdles to speaking the target language during the outbreak. According to the previous research that have been examined and discussed, there are numerous suggested interventions that have been demonstrated to be useful tools in overcoming ESL learners' obstacles and improving their language skills. These interventions include using social media such as WhatsApp, Facebook, YouTube and so on. As a result, educators must be aware of their learners' obstacles and provide solutions to their problems through interventions that address the learners' obstacles.

During this crisis, all institutions, including the government, universities and telecommunication companies, should take necessary precautions to safeguard the prospect of ESL learners in order to benefit from online teaching and learning. Reducing the accessibility problem will ultimately improve learners' motivation and success, concurrently preventing significant mental health problems which have adversely affected some learners. Furthermore, both learners and educators must be mentally and physically prepared to adapt to this new learning process as it is our "new norm" to survive COVID-19.

Finally, the findings of this study must be addressed to relevant authorities, such as institution administrators, Ministry of Education staff and policymakers especially on the importance of speaking skills during COVID-19 pandemic. This is to ensure they create a good strategy and put it into action for the efficacy of online teaching and learning, so that no learners would be left behind in utilizing the target language.

\section{Conflicts of Interest}

The authors declare no conflicts of interest regarding the publication of this paper. 


\section{References}

Aboagye, E., Yawson, J. A., \& Appiah, K. N. (2020). COVID-19 and E-Learning: The Challenges of Students in Tertiary Institutions. Social Education Research, 1, 109-115.

Adedoyin, O. B., \& Soykan, E. (2020). COVID-19 Pandemic and Online Learning: The Challenges and Opportunities. Interactive Learning Environment. https://doi.org/10.1080/10494820.2020.1813180

Alhumaid, K., Ali, S., Waheed, A., Zahid, E., \& Habes, M. (2020). COVID-19 \& E-Learning: Perceptions \& Attitudes of Teachers towards E-Learning Acceptance in the Developing Countries. Multicultural Education, 6, 100-115.

Al-Jumaili, A. A., Al-Rekabi, M. D., Alsawad, O. S., Allela, O. Q. B., Ryan, C. et al. (2017). Exploring Electronic Communication Modes between Iraqi Faculty and Students of Pharmacy Schools Using the Technology Acceptance Model. American Journal of Pharmaceutical Education, 81, 89. https://doi.org/10.5688/ajpe81589

Allam, S. N. S., Hassan, M. S., Mohideen, R. S., Ramlan, A. F., \& Kamal, R. M. (2020). Online Distance Learning Readiness during COVID-19 Outbreak among Undergraduate Students. International Journal of Academic Research in Business \& Social Sciences, 10, 642-657. https://doi.org/10.6007/IJARBSS/v10-i5/7236

Ariyanti, A. (2020). EFL Students' Challenges towards Home Learning Policy during COVID-19 Outbreak. Indonesian Journal of English Language Teaching and Applied Linguistics, 5, 167-175. https://doi.org/10.21093/ijeltal.v5i1.649

Arkorful, V., \& Abaidoo, N. (2015). The Role of E-Learning, Advantages and Disadvantages of Its Adoption in Higher Education. International Journal of Instructional Technology and Distance Learning, 12, 29-42. https://www.itdl.org/Journal/Jan 15/Jan15.pdf\#page=33

Asmara, R. (2020). Teaching English in a Virtual Classroom Using WhatsApp during COVID-19 Pandemic. Language and Education Journal, 5, 16-27.

Azam, F. K. K., Fadhil, F., \& Yunus, M. M. (2019). Enhancing ESL Learners' Writing Skills via ProvWrit. International Journal of Academic Research in Business and Social Sciences, 9, 660-669. https://doi.org/10.6007/IJARBSS/v9-i1/5467

Cakrawati, L. M. (2017). Students' Perception on the Use of Online Learning Platforms in EFL Classroom. English Language Teaching and Technology Journal, 1, 22-30.

Che Wil, C. S., Yunus, M. M., \& Suliman, A. (2019). The Use of Social Media to Assist Writing Skills among Secondary Pupils. International Journal of Academic Research in Progressive Education and Development, 8, 224-236.

https://doi.org/10.6007/IJARPED/v8-i3/6388

Chung, E., Subramaniam, G., \& Dass, L. C. (2020). Online Learning Readiness among University Students in Malaysia amidst COVID-19. Asian Journal of University Education, 16, 46-58. https://eric.ed.gov/?id=EJ1267359 https://doi.org/10.24191/ajue.v16i2.10294

Dizon, G. (2015). Japanese Students' Attitudes towards the Use of Facebook in the EFL Classroom. The Language Teacher, 39, 9-14.

Famularsih, S. (2020). Students' Experiences in Using Online Learning Applications Due to COVID-19 in English Classroom. Studies in Learning and Teaching, 1, 112-121. https://doi.org/10.46627/silet.v1i2.40

Faryadi, Q. (2017) Effectiveness of Facebook in English Language Learning: A Case Study. Open Access Library Journal, 4, e4017. https://doi.org/10.4236/oalib.1104017

Fauzi, I., \& Angkasawati, P. (2019). The Use of Listening Logs through WhatsApp in Improving Listening Comprehension of EFL Students. Journal of Applied Linguistics and 
Literature, 4, 13-26. https://doi.org/10.33369/joall.v4i1.6773

Ghavifekr, S., Kunjappan, T., Ramasamy, L., \& Anthony, A. (2016). Teaching and Learning with ICT Tools: Issues and Challenges from Teachers' Perceptions. MOJET Online Journal of Educational Technology, 4, 38-57.

Ghounane, N. (2020). Moodle or Social Networks: What Alternative Refuge Is Appropriate to Algerian EFL Students to Learn during COVID-19 Pandemic. Arab World English Journal ( $A$ WEJ), 11, 21-41. https://doi.org/10.24093/awej/vol11no3.2

Hernandez, S. S. F., \& Flórez, A. N. S. (2020). Online Teaching during COVID-19: How to Maintain Students Motivated in an EFL Class. Linguistics and Literature Review, 6, 157-171. https://doi.org/10.32350/llr.v6i2.963

Idrus, H., \& Salleh, H. I. (2007). Perceived Self-Efficacy of Malaysian ESL Engineering and Technology Students on Their Speaking Ability and Its Pedagogical Implications. The English Teacher, 37, 61-75.

Jasrial, D. (2018). Utilizing WhatsApp Application for Teaching English Language: Why and How. International Seminar and Annual Meeting BKS-PTN Wilayah Barat Fields of Language, Literature, Arts, and Culture, 1, 151-157.

Kaur, D., \& Aziz, A. A. (2020). The Use of Language Game in Enhancing Students' Speaking Skills. International Journal of Academic Research in Business and Social Sciences, 10, 687-706. https://doi.org/10.6007/IJARBSS/v10-i12/8369

Kerres, M. (2020). Against All Odds: Education in Germany Coping with COVID-19. Postdigital Science and Education, 2, 690-694.

https://doi.org/10.1007/s42438-020-00130-7

Khasbani, I. (2018). Revealing Teachers' Motivational Strategy in Indonesia EFL Classrooms. European Journal of English Language Teaching, 3, 1-14.

Kho, J. H. L., Chai, C. S., \& Lim, W. Y. (2016). Teacher Professional Development for TPACK-21CL: Effects on Teacher ICT Integration and Student Outcomes. Journal of Educational Computing Research, 55, 172-196. https://doi.org/10.1177/0735633116656848

Kisanjara, S. (2020). Factors Influencing E-Learning Implementation in Tanzanian Universities. The Online Journal of Distance Education and e-Learning, 8, 37-54.

Kukulska-Hulme, A., Lee, H., \& Norris, L. (2017). Mobile Learning Revolution: Implications for Language Pedagogy. In C. A. Chapelle, \& S. Sauro (Eds.), The Handbook of Technology and Second Language Teaching and Learning (pp. 217-233). Oxford: Wiley \& Sons. https://doi.org/10.1002/9781118914069.ch15

Layali, K., \& Al-Shlowiy, A. (2020). Students' Perceptions of e-Learning for ESL/EFL in Saudi Universities and their Implications during Coronavirus Pandemic: A Review of Literature. International Journal of English Language \& Translation Studies, 8, 64-72.

Lestiyanawati, R., \& Widyantoro, A. (2020). Strategies and Problems Face by Indonesian Teachers in Conducting E-Learning System during COVID-19 Outbreak. Journal of Culture, Literature, Linguistics and English Teaching, 2, 71-82.

Lim, J. K. S., \& Yunus, M. M. (2021). A Systematic Review of E-Learning in Teaching and Learning of Speaking Skills. International Journal of Academic Research in Business and Social Sciences, 11, 725-740.

Low, P., \& Warawudhi, R. (2016). Undergraduates' Attitudes towards the Use of Facebook in Fundamental English Course. International Journal of Information and Education Technology, 6, 934-939. https://doi.org/10.7763/IJIET.2016.V6.820

Mailizar, M., Almanthari, A., Maulina, S., \& Bruce, S. (2020). Secondary School Mathematics Teachers' Views on E-Learning Implementation Barriers during the COVID-19 
Pandemic: The Case of Indonesia. EURASIA Journal of Mathematics, Science and Technology Education, 16, em186. https://doi.org/10.29333/ejmste/8240

Manan, N. A. (2017). WhatsApp Mobile Tool in Second Language Learning. Indonesian EFL Journal, 3, 87-92. https://doi.org/10.25134/ieflj.v3i1.657

Mbukusa, N. R. (2018). Perceptions of Students' on the Use of WhatsApp in Teaching Methods of English as Second Language at the University of Namibia. Journal of Curriculum and Teaching, 7, 112-119. https://doi.org/10.5430/jct.v7n2p112

Meinawati, E., Harmoko, D. D., Rahmah, N. A., \& Dewi, N. (2020). Increasing English Speaking Skills Using YouTube. POLYGLOT: Jurnal Ilmiah, 16, 1-13.

Mishra, L., Gupta, T., \& Shree, A. (2020). Online Teaching-Learning in Higher Education during Lockdown Period of COVID-19 Pandemic. International Journal of Education Research Open, 1, Article ID: 100012. https://doi.org/10.1016/j.ijedro.2020.100012

Mistar, I., \& Embi, M. A. (2016). Students' Perception on the use of WhatsApp as a Learning Tool in ESL Classroom. Journal of Education and Social Sciences, 4, 96-104.

Mohamad, M., Arif, F. K. M., \& Noor, N. M. (2020). Online Game-Based Formative Assessment: Distant Learners Post Graduate Students' Positive Perceptions towards Quizizz. International Journal of Scientific \& Technology Research, 9, 1437-1444.

Mohamad, M., Rashid, N., \& Wan Mohamad, W. N. (2017). The Advantages and Disadvantages of E-Dictionaries to Enhance Vocabulary Learning of ESL Learners. The Asian Conference on Education \& International Development 2017 Official Conference Proceedings, Kobe, Japan, 26-29 March 2017, 315-325.

Musa, F., Mohamed, M., Mufti, N., Latiff, R. A., \& Amin, M. M. (2015). Incorporating Computer-Mediated Communication in Project Work. International Education Studies, 8, 150-157. https://doi.org/10.5539/ies.v8n5p150

Mustafa, M. B. (2015). One Size Does Not Fit All: Students' Perceptions about Edmodo at Al Ain University of Science \& Technology. Journal of Studies in Social Sciences, 13, 135-160.

Naz, S., Rasheed, M., \& Rasheed, T. (2019). The Role of Smartphones in Learning English: A Study of Learners' Perspectives. International Conference on Research in Humanities, London United Kingdom, 1, 17-28.

Octaberlina, L. R., \& Muslimin, A. I. (2020). ESL Students Perspective towards Online Learning Barriers and Alternatives Using Moodle/Google Classroom during COVID-19 Pandemic. International Journal of Higher Education, 9, 1-9. https://doi.org/10.5430/ijhe.v9n6p1

Oksana, C., \& Olena, S. (2021). E-Dictionary Use in Language Acquisition. Education and Science of Today: Intersectoral Issues and Development of Sciences, 2, 147-148.

Othman, J., Kadar, R., Umar, N., \& Ahmad, N. (2020). COVID-19 Pandemic Effects in Teaching and Learning Methods during Movement Control Order (MCO). Creative and Innovative Teaching Practices during COVID-19 Movement Control Order (MCO), 1 .

Pace, C., Pettit, S. K., \& Baker, K. S. (2020). Best Practices in Middle Level Quaranteaching: Strategies, Tips and Resources amidst COVID-19. Becoming: Journal of the Georgia Association for Middle Level Education, 31, 2-13. https://doi.org/10.20429/becoming.2020.310102

Pazilah, F. N., Hashim, H., \& Yunus, M. M. (2019). Using Technology in ESL Classroom: Highlights and Challenges. Creative Education, 10, 3205-3212. https://doi.org/10.4236/ce.2019.1012244

Rafiq, F., Hussain, S., \& Abbas, Q. (2020). Analyzing Students' Attitude towards E-Learning: 
A Case Study in Higher Education in Pakistan. Pakistan Social Sciences Review, 4, 367-380. https://doi.org/10.35484/pssr.2020(4-I)29

Rahaded, U., Puspitasari, E., \& Hidayati, D. (2020). The Impact of Whatsapp on UAD Undergraduate Students' Behavior in the Learning Process. International Journal of Educational Management and Innovation, 1, 55-68. https://doi.org/10.12928/ijemi.v1i1.1515

Rajendran, T., \& Yunus, M. M. (2021). A Systematic Literature Review on the Use of Mobile Assisted Language Learning (MALL) for Enhancing Speaking Skills among ESL and EFL Learners. International Journal of Academic Research in Progressive Education and Development, 10, 586-609. https://doi.org/10.6007/IJARPED/v10-i1/8939

Rashid, N., Yunus, M. M., \& Mohamad, M. (2015). E-Dictionary and ESL Learners. The 4th International Conference on Learner Diversity Conference, AKEPT, Bandar Enstek Nilai, Negeri Sembilan, December 2015, 575-581.

Rasmitadila, R., Aliyyah, R. R., Rachmadtullah, R., Samsudin, A., Syaodih, E., Nurtanto, M., \& Tambunan, A. R. S. (2020). The Perceptions of Primary School Teachers of Online Learning during the COVID-19 Pandemic Period: A Case Study in Indonesia. Journal of Ethnic and Cultural Studies, 7, 90-109. https://doi.org/10.29333/ejecs/388

Rohman, M., Marji, Sudjimat, D. A., Sugandi, R. M., \& Nurhadi, D. (2020). Online Learning in Higher Education during COVID-19 Pandemic: Students' Perceptions. Journal of Talent Development and Excellence, 12, 3644-3651.

Savasci, M. (2013). Why Are Some Students Reluctant to Use L2 in EFL Speaking Classes? An Action Research in Tertiary Level. Procedia-Social and Behavioral Sciences, 116, 2682-2686. https://doi.org/10.1016/j.sbspro.2014.01.635

Sayuti, H. A. M., Teh, G. A., Saimi, W. M. S. A., Bakar, M. A., Dawawi, S. N. A., \& Mohamad, M. (2020). Using Gold Standard Project Based Learning for Intermediate Year Three Pupils to Enhance English Speaking Skill: A Conceptual Paper. Creative Education, 11, 1873-1889. https://doi.org/10.4236/ce.2020.1110137

Shahzad, S. K., Hussain, J., Sadaf, N., Sarwat, S., Ghani, U., \& Saleem, R. (2020). Impact of Virtual Teaching on ESL Learners' Attitudes under COVID-19 Circumstances at Post Graduate Level in Pakistan. English Language Teaching, 13, 1-9.

https://doi.org/10.5539/elt.v13n9p1

Simamora, R. M. (2020). The Challenges of Online Learning during the COVID-19 Pandemic: An Essay Analysis of Performing Arts Education Students. Studies in Learning and Teaching, 1, 86-103. https://scie-journal.com/index.php/SiLeT/article/view/38/21 https://doi.org/10.46627/silet.v1i2.38

Sison, M. O., \& Bautista, S. C. (2021). Technical Capability, Instructional Strategies and Learners' Engagement in Online Learning Instruction: Basis for Framework Development. International Journal of Academic Research in Progressive Education and Development, 10, 261-287.

Suhaimi, N. D., Mohamad, M., \& Yamat, H. (2019). The Effects of WhatsApp in Teaching Narrative Writing: A Case Study. Humanities \& Social Sciences Reviews, 7, 590-602. https://doi.org/10.18510/hssr.2019.7479

Sukendro, S., Habibi, A., Khaeruddin, K., Indrayana, B., Syahruddin, S., Makadada, F. A., \& Hakim, H. (2020). Using an Extended Technology Acceptance Model to Understand Students' Use of E-Learning during COVID-19: Indonesia Spot Science Education Context. Heliyon, 6, e05410. https://doi.org/10.1016/j.heliyon.2020.e05410

Suvarchala Rani, M., Rajini, P., \& Lal, K. (2020). Students' Perception towards Online Learning in Higher Education: A Structural Equation Modeling Analysis. International Journal of Management, 11, 672-687. 
Syafiq, A. N., Rahmawati, A., Anwari, A., \& Oktaviana, T. (2021). Increasing Speaking Skill through YouTube Video as English Learning Material during Online Learning in Pandemic COVID-19. Elsya: Journal of English Language Studies, 3, 50-55.

https://doi.org/10.31849/elsya.v3i1.6206

Toquero, C. M. (2020). Challenges and Opportunities for Higher Education amid the COVID-19 Pandemic: The Philippine Context. Pedagogical Research, 5, em0063. https://doi.org/10.29333/pr/7947

Verawardina, U., Asnur, L., Lubis, A. L., Hendriyani, Y., Ramadhani, D., Dewi, I. P., Darni, R., Betri, T. J., Susanti, W., \& Sriwahyuni, T. (2020). Reviewing Online Learning Facing the COVID-19 Outbreak. Journal of Talent Development and Excellence, 12, 385-392.

Wang, C. J., Ng, C. Y., \& Brook, R. H. (2020). Response to COVID-19 in Taiwan: Big Data Analytics, New Technology, and Proactive Testing. JAMA, 323, 1341-1342. https://doi.org/10.1001/jama.2020.3151

Wargadinata, W., Maimunah, I., Dewi, E., \& Rofiq, Z. (2020). Student's Responses on Learning in the Early COVID-19 Pandemic. Tadris: Journal of Education and Teacher Training, 5, 141-153. https://doi.org/10.24042/tadris.v5i1.6153

Yen, E. L. Y., \& Mohamad, M. (2020). Utilising E-Learning to Assist Primary School ESL Pupils in Learning to Spell during COVID-19 Pandemic: A Literature Review. Creative Education, 11, 1223-1230. https://doi.org/10.4236/ce.2020.118091

Yilmaz, R. (2017). Exploring the Role of E-Learning Readiness on Student Satisfaction and Motivation in Flipped Classroom. Computers in Human Behavior, 70, 251-260. https://doi.org/10.1016/j.chb.2016.12.085

Zakaria, A. H., \& Shah, P. M. (2019). Communicative Language Teaching (CLT): Its Implementation in Teaching English to Malaysian ESL Primary Learners. International Journal of Scientific \& Engineering Research, 10, 785-799. 